\title{
THE IMPACT OF US CRISIS ON TRADE AND STOCK MARKET IN INDONESIA
}

\author{
Mita Nezky
}

\begin{abstract}
This paper analyzes the impact of the 2008 financial crisis in United States on the Indonesian economy, by using the Structural Vector Autoregression (SVAR) model of 5 variables; the Dow Jones Industrial Average, the exchange rate, the Jakarta Composite Index (JCI), the production index, and the international trade tax income. The results showed that the US crisis affected the capital market in Indonesia, where the Dow Jones Industrial Average plays a greater role in explaining the JClcompared to Rupiah exchange rate, production index and the trade income tax. In addition, the US crisis affected the volume and the trade income tax in Indonesia. These empirical results have policy implications for the Capital Market and Financial Institution Supervisory Board (BAPPEPAM-LK) as the stock market regulator to intervene or to suspend the trade in stock market when volatility exceeds the psychological threshold. The results also emphasized the necessity to diversify the country's export destinations and to increase the quality and the value-added of Indonesian exports.
\end{abstract}

Keywords : US Crisis, stock market, trade, SVAR.

\section{JEL Classification : G18}

1 Mita Nezky, ME is graduated from Master of Economic in Public Policy, University of Indonesia; mitanezky@rocketmail.com. 


\section{INTRODUCTION}

The U.S. economy is the largest economy in the world with a GDP of $\$ 15.5$ trillion $^{2}$ by the end of 2011 (one quarter of world GDP). Before the financial crisis in 2008, steady economic growth resulted in low unemployment and inflation in the United States. In early 2007, the unemployment rate in the United States was $4.4 \%$ with an inflation rate of $2.1 \%$. During the crisis of 2008 , the unemployment rate in the United States increased to $6.8 \%$ with an inflation rate of $5.6 \%^{3}$.

In mid-2007, the U.S. experienced a subprime mortgage crisis that peaked in September 2008 , and was subsequently marked by the announcement of the bankruptcy of several financial institutions. The beginning of the problems occurred in 2000-2001, when the dotcom ${ }^{4}$ stocks in the United States collapsed, and the companies that issued shares could not repay the loans to the bank. To overcome this, the Federal Reserve (U.S. Central Bank) cut interest rates. Low interest rates were used by developers and housing finance companies. The houses built by developers and financed by the housing finance companies were cheap homes, sold to low-income home-buyers who had inadequate financial guarantees. With the collapse of the stock value of these companies, the banks were facing defaults of the debtor (developers and housing financing companies).

According to Crockett (1997), financial stability is closely related to the health of an economy. The more healthy a country's financial sector, the more healthy the economy, and vice versa. Thus, the development of the financial sector, including capital markets, is a key indicator to maintain a healthy or stable economy. Price movements of stocks, bonds, and other securities in the stock market of a country are a reflection of investors' perception of the condition of the capital markets. This perception will ultimately affect investment funds coming into the country, and likewise affect the state of the economy concerned. This is not exclusive to the United States, as it is also prevalent in Europe and Asia, including Indonesia.

The Rupiah exchange rate against the U.S. dollar began to decline from mid-2008 and continued to depreciate until it reached its lowest level at the beginning of 2009 at the amount of Rp. 11,900 per 1 USD. Changes in exchange rates, either appreciation or depreciation will affect import-export activities in the country, because the USD is still the dominant currency in global trade payments.

The increase or decrease in exports and imports will affect state revenues derived from international trade taxes. Depreciation of the Rupiah mid-2008 led to an increase in exports that affected the acceptance of duties and taxes, in particular international trade in general. Changes in the value of exports and imports also affect the Gross Domestic Product (GDP) of

2 International Financial Statistics (IMF, 2011).

3 Ibid.

4 Dotcom companies are the companiesthat run most of its business on the internet, for example, www.amazon.com ; www.amcy. com; www.e-loft.com; www.flooz.com; etc. 
Indonesia. The production index is an economic indicator that is often used to replace the GDP as its data publication is done every month.

Given the background above, this paper analyzes how the U.S. financial crisis 2007-2011 affected capital markets in Indonesia and the Indonesian government revenue derived from international trade taxes. Explicitly, the first purpose of this paper is to examine whether there was any effect of the U.S. financial crisis on Indonesia's capital market and revenues derived from international trade taxes; and second, to provide policy recommendations in order to maintain the stability of the Indonesian capital markets and fixed increase government revenue from international trade taxes (ITT).

The second part of this paper will examine theoretical basis, and the third part will review the data and methodology used for the analysis. Results and analysis are presented in the fourth section, while the conclusions and recommendations are presented in the last section to complete this paper.

\section{THEORY}

The financial crisis can be attributed to a few key things; first, the failure of the financial market, second, a situation in which an institution or a financial institution lost most of its assets, third, banking panic, credit defaults and the recession, and fourth, the collapse of the stock exchange and falling currency values (see among others, Mishkin (1992), Allen (2001), Eichengreen and Portes (1987), and Jickling (2008)).

Many researchers have investigated financial crises and these crises are generally divided into three types according to the background and the characteristics of the crisis. The firstgenerationof crisis-related fiscal and monetary problems commenced with a crisis in Mexico 1973-1982 (Kaminsky, 2003). Flood and Garber (1984) and Krugman (2007) further stated that in addition to fiscal and monetary issues, first generation crisis were caused by macroeconomic instability. Alongside this, a currency crisis can also be caused by a government's budget deficit and a system of fixed exchange rates.

Second generation crisis was first presented by Obstfeld (1994) and Cole and Keho (1996). One example of this event is the crisis that hit the European financial system in 1992 and 1993. According to Obstfeld, second-generation crisis is a crisis caused by the application of the conflict of fixed exchange rates against the government's desire for monetary expansion.

Third generation crisis is a combination of the first and second generation crises, as such it is also known as the twin crises. According to Krugman (2001), Cartapanis and Gilles (2002), twin crises are caused by a worsening of the banking system and a drop in the exchange rate. One example of the twin crises is crises that hit Asia in 1997. According to Kaminsky and Reinhart (1999), twin crises are caused by weak economic fundamentals of the country. In 2003, Kaminsky added that the cause of the third generation crises is also a crisis of moral 
hazard and asymmetric information. This type of crisis is characterized by anincrease total credit and a sudden rise in asset prices.

Various empirical studies have been conducted of the financial crises, some of which examined the relationship between the financial crisis with the stock indices, exchange rates, trading volumes, and revenues from international trade. However, in the author's opinion, little research has been done on the relationship of a financial crisis with international trade taxes. Therefore, the author's interest is to explore the effect of the financial crisis on international trade taxes.

This paper refers to research conducted by Fang, Lai, and Thompson (2007) and Zhang brothers and Han (2010), but research for this thesis puts more emphasis on international trade taxes. Fang, Lai, and Thompson (2007) to did more research on the exchange rate and exports. According to Fang, Lai, and Thompson (2007), there is an (positive) influence between the exchange rate depreciation on export revenues in eight countries in Asia. However, there is not always a positive relationship between exchange rate depreciation with export revenues because the declining value of the currency is not always accompanied by increased export demand. In addition, exchange rate risks encourage exporters to hedge.

Research on the relationship between financial crises with international trade was also carried out by the Zhang brothers and Han (2010). They assumed that the U.S. financial crisis affected the state of the economy in the Asia Pacific region through the trade channel. More specifically, their study showed that the financial crisis of the United States economy affected the Asia Pacific region through three channels, namely the banking sector, flight-to-quality, and the stock market.

\section{METHODOLOGY}

\subsection{Data and Variables}

Monthly time series data from January 2007 to December 2011 were used in preparing this paper. The period was determined by the movement of the financial crisis in the United States. Monthly data was used to capture the movement and to provide a more accurate analysis of changes in variables such as the Dow Jones Industrial Average (DII), Jakarta Composite Index $(\mathrm{JCl})$, and exchange rates (Euro against the USD) that occurred within a relatively short time.

The data used was quite diverse in measurement unit. Data from the DJ, JCl, and EXCRATE have units inthe thousandths, the hundredths for PI, while the data units for ITT are in the trillions. To make the data more uniform to facilitate interpretation, it was converted usinga natural logarithm. According Nachrowi and Usman (2006), using a logarithmic transformation of the data is intended to minimize the scale between the independent variables. If the range of values observed become increasinglynarrow, the expected variation of the error will not differ across groups of observations. 


\subsection{Estimation Technique}

This paper uses a Structural Vector Autoregression (SVAR) model for making data estimates. The estimation technique is preceded by some standard steps including stationarity test data or stationary stochastic process (Ajija et.al, 2011), and the determination of the optimal number of lag with lag order selection criteria. In this study, the amount of lag will be determined based on the criteria with longest lag.

The SVAR model is a development of the VAR model that was first introduced by Christopher Sims (1980). According to Sims, if there is a simultaneous relationship between observed variables then these variables should be treated equally; there would be no endogenous and exogenous variables. Development within the SVAR model is done by setting restrictions on cross-variable correlation in the system of equations. Limitations or restrictionsare intended to separate the movement of the endogenous variables into several components with reference to the underlying shock. According to Enders (2003), Structura/ VAR is used to prove an economic theory or to seek theoretical basis of a shock (Bilmeier and Bonatot, 2002).

The Structural VAR model used in this paper consists of five variables that make up the five equations, where the Dow Jones Industrial Average (DJI) is used as a proxy of a crisis in America, the Jakarta Composite Index (JCI) as a proxy of the state of capital markets in Indonesia, the value of the Rupiah against the USD, the production index as a proxy of the state of the Indonesian economy (GDP), and international trade taxes as a proxy of state revenue. The specific SVAR model in reduced form is,

$$
A_{0} X_{t}=A(L) X_{t-1}+B \varepsilon_{t}
$$

where $X_{t}$ is a vector for five variables used (DJI, CJI, EXCRATE, PI, and ITT); $A_{0}$ iscontemporaneous relations between variables; $A(L)$ is the finite-order matrix polynomial with the lag operator $L_{;} \varepsilon_{t}$ is the vector structural disturbance; and $B$ is a non-zero diagonal matrix.

Basically, there are several ways to set restrictions on the SVAR model, among others are the long run restriction, impact, and the sign restriction. These restrictions help in the identification of the model and also functions in applying theory to the model.

The Dow Jones Industrial Average variable is considered an independent variable so that the variable that can influenceit is the shock of Dow Jones Industrial Average itself. Shock of Jakarta Composite Index $(\mathrm{JCI})$, exchange rate, production index, and international trade taxes cannot be considered to affect the shock to the Dow Jones Industrial Average. Thus, the first equation in the SVAR system is as follows:

$$
e_{D J I}=b_{11} \varepsilon_{D J I}
$$


Shock to the Jakarta Composite Index $(\mathrm{JCl})$ is affected by the shock of the Dow Jones Industrial Average since the event of shock on the Dow Jones Industrial Average; Jakarta Composite Index $(\mathrm{JCI})$ is the first variables that respond to shock. It follows that shock to the Composite Stock Index is influenced by the Dow Jones Industrial Average shock and shock on Jakarta Composite Index (JCI) itself.

$$
e_{I H S G}=b_{21} \varepsilon_{D J I}+\varepsilon_{I H S G}
$$

If there is a shock in the Dow Jones Industrial Average which is followed by a shock in the Jakarta Composite Index $(\mathrm{JCI})$, and then a shock in the exchange rate, these events would be associated with production activities for exports and imports, where the production index is assumed to respond to shocks in the first place. There fore, shock on the production index is affected by the shock on the Dow Jones Industrial Average, shock on Jakarta Composite Index $(\mathrm{JCl})$, the exchange rate shock, and a shock to the production index itself.

$$
e_{I P}=b_{41} \varepsilon_{D J I}+b_{42} \varepsilon_{I H S G}+b_{43} \varepsilon_{\text {excrate }}+\varepsilon_{I P}
$$

The exchange rate is assumed to be influenced by shock to the Dow Jones Industrial Average (DJI), shock to the Jakarta Composite Index $(\mathrm{JCl})$, and shock to the exchange rate itself. On the other hand, the shock on the international trade tax is assumed to be influenced by shock to the Dow Jones Industrial Average, shock on the Jakarta Composite Index (JCI), the exchange rate shock, the shock on the production index, and a shock to the international trade tax itself.

$$
\begin{aligned}
& e_{\text {excrate }}=b_{31} \varepsilon_{D J I}+b_{32} \varepsilon_{I H S G}+\varepsilon_{\text {excrate }} \\
& e_{P P I}=b_{51} \varepsilon_{D J I}+b_{52} \varepsilon_{I H S G}+b_{53} \varepsilon_{\text {excrate }}+b_{54} \varepsilon_{I P}+\varepsilon_{P P I}
\end{aligned}
$$

Basically, the restriction used refers to Sims (1980) where $C_{0} \varepsilon_{t}=e t$, then $C_{0}$ is restricted as a triangular matrix, providing a system that is just identified. Matrix $C_{0}$ is a measure of impact of structural shock from the endogenous variables thus it is classified as impact restriction, with a number of restrictions as $n x(n-1) / 2$ or in this case as much as 10 (ten) restrictions. In addition, the author also provides an additional restriction to the diagonal elements $b_{11}=b_{22}=\ldots b_{55}=1$, so the equation system becomes over-identified. This additional restriction is a normalization model for ease of interpretation where the reduced form disturbance (e) will correspond with the structural shock $(\varepsilon)$. Normalization is merely scaling that does not change the essence and interpretation of the estimated results. Thus, with a total of 15 restrictions, the SVAR system specifications used are as follows: 


$$
\left[\begin{array}{c}
e_{D J I} \\
e_{I H S G} \\
e_{\text {excrate }} \\
e_{I P} \\
e_{P P I}
\end{array}\right]=\left[\begin{array}{c}
\varepsilon_{D J I} \\
\varepsilon_{I H S G} \\
\varepsilon_{\text {excrate }} \\
\varepsilon_{I P} \\
\varepsilon_{P P I}
\end{array}\right]\left[\begin{array}{ccccc}
1 & 0 & 0 & 0 & 0 \\
b_{21} & 1 & 0 & 0 & 0 \\
b_{31} & b_{32} & 1 & 0 & 0 \\
b_{41} & b_{42} & b_{43} & 1 & 0 \\
b_{51} & b_{52} & b_{53} & b_{54} & 1
\end{array}\right]
$$

To ensure the validity of the final model used, testing was done for the stability of the model on the condition that the entire root lies inside the unit circle (absolute value less than one unit root). If the condition is stable, the next step is the Impulse Response Function (IRF) and Variance Decomposition (VD).

\section{ANALYSIS AND RESULTS}

From the stationarity test, the results obtained indicate that all the variables were stationary in first differences. Based on the testing of lag length, the recommended amount of lag is lag 1 and lag 2. The selected optimal lag is Lag 1 (one) on the basis that the longer the lag, the more observations that are 'missing' (Nachrowi and Usman, 2006). By using Inverse Roots of $A R$ Characteristics polynomial, the estimated empirical model is proved to be stable,hence can be used to analyze the Structural Impulse Response Function and Variance Decomposition.

\subsection{Impulse Response Function}

Figure 1 shows the impulse response function of the variables studied. When there is a decline in the Dow Jones Industrial (DJI), The Jakarta Composite Index (JCI) will drop until month 12 and then increase to neutral after 40 months. The impulse response function above indicates that The Jakarta Composite Index $(\mathrm{JCI})$ will immediately respond to a reduction in the Dow Jones.

The DJI decline triggered a liquidity crisis among American and European investors that also affected the Jakarta Composite Index (JCI). While in Indonesia, domestic investors experienced panic and uncertainty over the state of the economy that caused The Jakarta Composite Index $(\mathrm{JCl})$ to plummet. The positive influence of the shock will occur within a period of 12 months. After that period, Jakarta Composite Index $(\mathrm{JCI})$ would respond opposite (negative) of the DJI. This is caused by the re-entry of funds characterized by the growth of investor confidence in the country so as to attract foreign investors to invest their funds in the Jakarta Composite Index $(\mathrm{JCI})$. According to the IRF, the effect of the DJI shock becomes neutral (no effect) within 40 months. In that time frame it is expected that investors both within and outside the country would have received confirmation that the economy is no longer influenced the DJ shock. 
Respons of DEXCRATE_LN to Shock 1

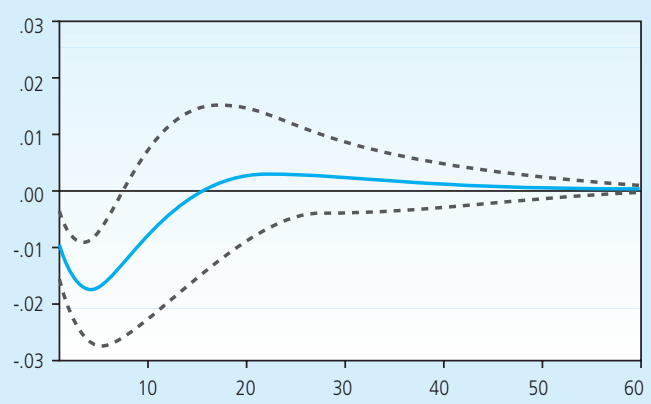

Response of DEXCRATE_LN to Shock 2

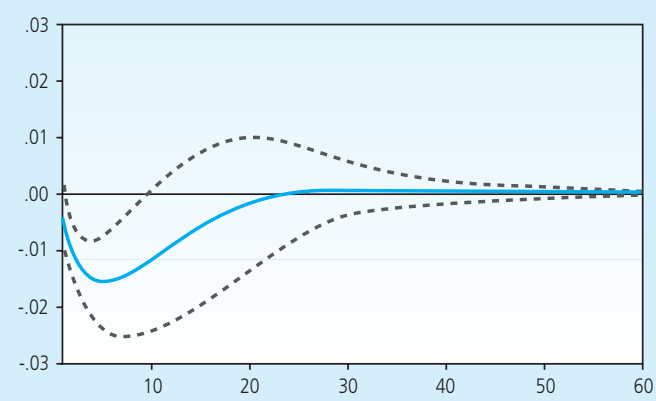

Response of DIHSG_LN to Shock 1

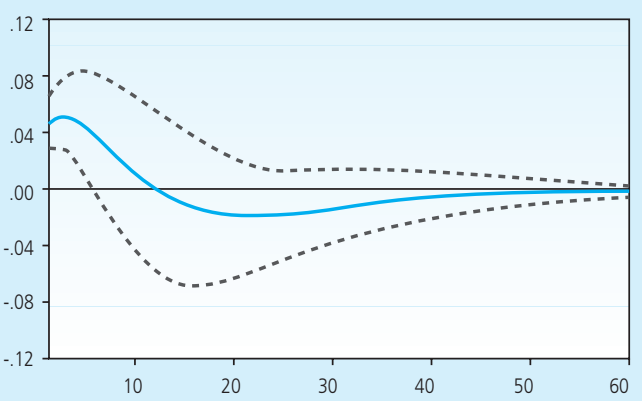

Response of DPPI_LN to Shock 3

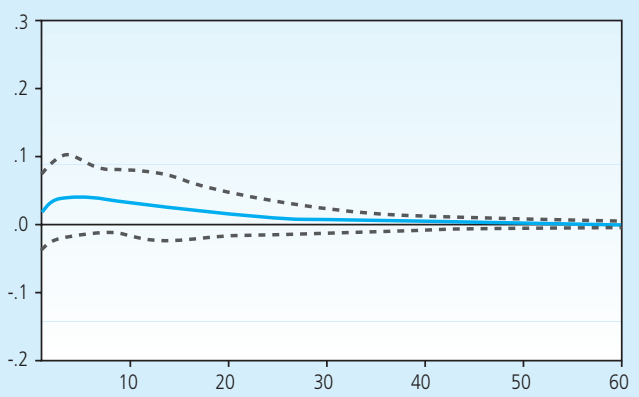

Response of DPPI_LN to Shock 1

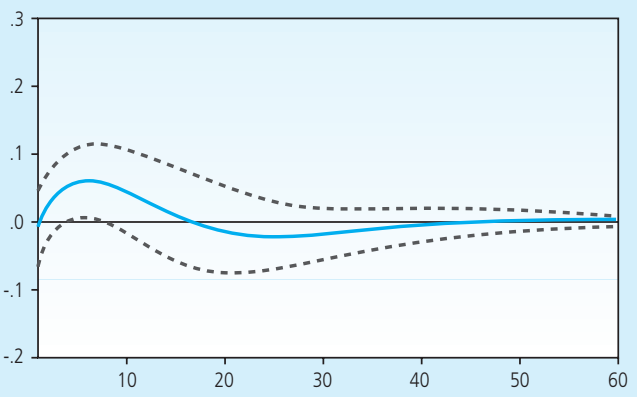

Figure 1.

Impulse Response Function

In terms of exchange rate movements of the Rupiah against the U.S. dollar, the IRF results show that when the Dow Jones (DJI) average index increase, then the Rupiah would weaken against the USD. A DJI decline will reduce liquidity in USD in the domestic market of various countries so that the USD will be weakened. Weakening of the USD does not directly strengthen the Rupiah. According to the Chief Economist at PT. Bank Mandiri, Destry Damayanti, speculation of homeland expectations of economic conditions make investors hold on to their USD which 
weakens the Rupiah. In addition, the current account deficit caused by the increasing number of imports (due to a weakening USD makes the price of foreign goods cheaper than domestic goods), which worsens the strength of the Rupiah. Based on the IRF graph, the condition will last about 40 months and then became neutral (no effect).

The Jakarta Composite Index (JCl) has an impact on dollar value that can be seen from the Figure 1. The Jakarta Composite Index $(\mathrm{JCl})$ decline will put pressure on the Rupiah resulting in depreciation. The Jakarta Composite Index $(\mathrm{JCI})$ will also cause a decline in dollar liquidity in the domestic market so that the minimum value of the rupiah would weaken. Based on the Figure 1, the condition will last about 40 months and then become neutral (with no effect). This same period of turbulence and stabilization is seen for the stock index in response to a DJI shock which explains why the exchange rate (EXCRATE) will stabilize within a period of 40 months from the effects of shock to the $\mathrm{JCl}$.

If the dollar is depreciating, the value of the goods in the country (Indonesia) is relatively less expensive compared to the price of foreign goods which would lead to increased exports. However, the declining purchasing power in the United States caused by the financial crisis, has affected trade activities in US and other countries that made the United States an export destination. This will directly and indirectly affect the level of Indonesia's exports. According to the Figure 5, the EXCRATE shock effect would be neutral in a period of 36 months.

In aggregate, the growth of Indonesia's exports decreased from 9.5\% in 2008 to 5.9 in $2009 \%$. A slowing export growth due to reduction on global demand, which is triggered by the world recession, caused a slowdown in manufacturing and agricultural exports, falling commodity prices (mined goods wereone-fifth the price in 2007 compared to the price in 2006), and rising global unemployment rate affected the production level of export commodity especially processing and craft commodity.

The Dow Jones was also affected by the international trade taxes (ITT). A decrease in the DJI will reduce the liquidity of the USD in the United States domestic market and will affect Indonesia's purchasing power and exports to this country. Based on Statistic Indonesia data obtained from the website, the value of Indonesia's exports to the United States decreased by USD 2 trillion during 2008 to 2009. This decline in export value depressed the trade tax income (ITT). In the 19th month ITT started to rise, and exporters began eyeing export destinations other than the United States and beyond. In addition, the increase in ITT was also caused by increased imports. The effect of the shock became neutral at month 40 as the import/export market conditions is expected to be stable by that time. 


\begin{tabular}{|c|c|c|c|c|c|c|c|c|c|c|c|}
\hline \multicolumn{12}{|c|}{$\begin{array}{l}\text { Table } 1 . \\
\text { Value Trade with Major Trading Partners to Indonesia, 2007-2011 (million USD) }\end{array}$} \\
\hline \multirow{2}{*}{ No } & \multirow{2}{*}{ Country } & \multicolumn{2}{|c|}{2007} & \multicolumn{2}{|c|}{2008} & \multicolumn{2}{|c|}{2009} & \multicolumn{2}{|c|}{2010} & \multicolumn{2}{|c|}{2011} \\
\hline & & Export & Import & Export & Import & Export & Import & Export & Import & Export & Import \\
\hline 1 & Japan & 23,633 & 6,527 & 27,744 & 15,128 & 18,575 & 9,844 & 25,782 & 16,966 & 33,715 & 19,437 \\
\hline 2 & China & 9,676 & 8,558 & 11,636 & 15,247 & 11,499 & 14,002 & 15,693 & 20,424 & 22,941 & 26,212 \\
\hline 3 & United States & 11,614 & 4,787 & 12,977 & 7,880 & 10,852 & 7,084 & 14,267 & 9,399 & 16,441 & 10,813 \\
\hline 4 & Singapore & 10,502 & 9,840 & 12,862 & 21,789 & 10,263 & 15,550 & 13,723 & 20,241 & 18,444 & 25,965 \\
\hline 5 & Republicof Korea & 7,583 & 3,197 & 9,117 & 6,920 & 8,145 & 4,742 & 12,575 & 7,703 & 16,389 & 13,000 \\
\hline 6 & India & 4,944 & 1,610 & 7,163 & 2,902 & 7,433 & 2,209 & 9,915 & 3,295 & 13,336 & 4,322 \\
\hline 7 & Malaysia & 5,096 & 6,412 & 6,433 & 8,922 & 6,812 & 5,688 & 9,362 & 8,649 & 10,996 & 10,405 \\
\hline 8 & Australia & 3,395 & 3,004 & 3,775 & 3,998 & 3,264 & 3,436 & 4,244 & 4,099 & 5,583 & 5,177 \\
\hline 9 & Thailand & 3,054 & 4,287 & 3,661 & 6,334 & 3,234 & 4,613 & 4,567 & 7,471 & 5,897 & 10,405 \\
\hline 10 & Taiwan & 2,597 & 1,495 & 3,155 & 2,850 & 3,382 & 2,393 & 4,838 & 3,242 & 6,585 & 4,260 \\
\hline
\end{tabular}

Based on data obtained in 2012 from CBS, the United States is Indonesia's third largest export destination after Japan and China, then followed by other Asian countries such as Singapore, the Republic of Korea, and India. A decrease in purchasing power of the United States led to decreased demand for imports which in turn affected the value of Indonesia's exports to the United States. The composition Indonesia exports from 2007 to 2011 consisted of $20.38 \%$ in oil and gas exports, and $79.62 \%$ in non-oil exports. Although the value of Indonesia's exports

Table 2.

Main Destination Countries of Non-Oil and Gas Industry Export of Indonesia, 2007-2011 (in million USD, and percentage)

\begin{tabular}{|c|c|c|c|c|c|c|}
\hline No & Country & 2007 & 2008 & 2009 & 2010 & 2011 \\
\hline 1 & United States & $\begin{array}{r}10,360.70 \\
13.55 \% \\
\end{array}$ & $\begin{array}{r}11,398.60 \\
12.90 \% \\
\end{array}$ & $\begin{array}{r}9,377.06 \\
12.77 \% \\
\end{array}$ & $\begin{array}{r}12,188.79 \\
12.44 \% \\
\end{array}$ & $\begin{array}{r}14,479.98 \\
11.85 \% \\
\end{array}$ \\
\hline 2 & Japan & $\begin{array}{r}9,655.87 \\
12.63 \%\end{array}$ & $\begin{array}{r}9,352.50 \\
10.58 \% \\
\end{array}$ & $\begin{array}{r}7,034.54 \\
9.58 \% \\
\end{array}$ & $\begin{array}{r}10,020.13 \\
10.22 \% \\
\end{array}$ & $\begin{array}{r}12,577.41 \\
10.29 \% \\
\end{array}$ \\
\hline 3 & China & $\begin{array}{r}5,487.69 \\
7.18 \% \\
\end{array}$ & $\begin{array}{r}6,245.18 \\
7.07 \% \\
\end{array}$ & $\begin{array}{r}6,002.22 \\
8.17 \% \\
\end{array}$ & $\begin{array}{r}8,046.78 \\
8.21 \%\end{array}$ & $\begin{array}{r}10,877.24 \\
8.90 \%\end{array}$ \\
\hline 4 & Singapore & $\begin{array}{r}8,681.64 \\
11.35 \%\end{array}$ & $\begin{array}{r}9,726.97 \\
11.00 \%\end{array}$ & $\begin{array}{r}7,594.37 \\
10.34 \%\end{array}$ & $\begin{array}{r}9,095.97 \\
9.28 \%\end{array}$ & $\begin{array}{r}10,717.96 \\
8.77 \%\end{array}$ \\
\hline 5 & India & $\begin{array}{r}3,416.03 \\
4.47 \%\end{array}$ & $\begin{array}{r}5,437.22 \\
6.15 \% \\
\end{array}$ & $\begin{array}{r}4,639.70 \\
6.32 \% \\
\end{array}$ & $\begin{array}{r}6,331.12 \\
6.46 \% \\
\end{array}$ & $\begin{array}{r}7,426.97 \\
6.08 \% \\
\end{array}$ \\
\hline 6 & Malaysia & $\begin{array}{r}3,843.66 \\
5.03 \%\end{array}$ & $\begin{array}{r}4,819.53 \\
5.45 \% \\
\end{array}$ & $\begin{array}{r}4,318.16 \\
5.88 \% \\
\end{array}$ & $\begin{array}{r}5,981.21 \\
6.10 \% \\
\end{array}$ & $\begin{array}{r}7,063.50 \\
5.78 \%\end{array}$ \\
\hline 7 & Netherland & $\begin{array}{r}2,646.19 \\
3.46 \%\end{array}$ & $\begin{array}{r}3,603.93 \\
4.08 \% \\
\end{array}$ & $\begin{array}{r}2,636.78 \\
3.59 \% \\
\end{array}$ & $\begin{array}{r}3,375.66 \\
3.44 \% \\
\end{array}$ & $\begin{array}{r}4,736.76 \\
3.88 \%\end{array}$ \\
\hline 8 & Thailand & $\begin{array}{r}2,216.43 \\
2.90 \%\end{array}$ & $\begin{array}{r}2,542.12 \\
2.88 \%\end{array}$ & $\begin{array}{r}1,973.94 \\
2.69 \%\end{array}$ & $\begin{array}{r}3,249.16 \\
3.31 \%\end{array}$ & $\begin{array}{r}4,220.70 \\
3.45 \%\end{array}$ \\
\hline
\end{tabular}


to the United States was only 9\% (on average in the period 2007-2011), the United States is the main destination of Indonesia's non-oil industries exports (Table 2), hence changes in demand for U.S. exports would greatly affect the value of exports from Indonesia as a whole.

\subsection{Structural Variance Decomposition}

Variance decomposition of the forecast error equation system gives information of how large the role of each variable in explaining variation in a particular variable in the SVAR system. Changes in the DJI (Dow Jones Industrial Average) play a greater role in explaining changes of Jakarta Composite Index (JCI), compared to EXCRATE (the exchange rate), PI (Production Index) and ITT (International Trade Tax). The bankruptcy of major financial firms like Lehman Brothers in 2008 led to panic as investors pulled their money out of the stock and pushed flight-to-quality. This causeda drop in the Jakarta Composite Index to its lowest level. A number of companies in the United States and Europe were experiencing a liquidity crisis and panic that encouraged domestic investors' impairment to theJakarta Composite Index (JCI).

On the other hand, the estimated results indicate that changes in the Jakarta Composite Index $(\mathrm{JCl})$ has larger role in explaining changes in EXCRATE (exchange rate) compared to changes in the DJI (Dow Jones Industrial Average), PI (Production Index) and ITT (International Trade tax). The Jakarta Composite Index (JCI) is an index of major stocks that describes the movement of stock prices in the Indonesia stock exchange with a market capitalization of Rp. 3.4 Trillion. If there is a decrease The Jakarta Composite Index (JCI), investors will pull their money out of the stock, causing liquidity in the Indonesian domestic market to increase. This will cause the value of dollar to decline or depreciate.

$\mathrm{JCl}$ changes also play a role in explaining changes in $\mathrm{PI}$ (Production Index) compared changes in DJ (Dow Jones Industrial Average), EXCRATE (exchange rate), and the ITT (International Trade Tax). Jakarta Composite Index (JCI) is a stock index comprised of large companies that have gone public such as the PT. Astra Agro Lestari (plantations), PT. Bumi Resources Tbk (mining), Elnusa Tbk (mining), Dynaplast Tbk (industrial), Betonjaya Manunggal Tbk (industry), Barito Pacific Tbk (industry), Gajah Tunggal Tbk (industry). Changes in The Jakarta Composite Index $(\mathrm{JCl})$ would cause an increase or decrease in the value of the industrial companies incorporated in The Jakarta Composite Index (JCI) that will also affect the value of PI (Production Index). If the value of Jakarta Composite Index $(\mathrm{JCI})$ declined the book value of these companies will decline and will affect their assets and capital. It will affect the activities of production, production output and production indices in the end.

Although associated with international trade taxes (ITT), changes in the DJ (Dow Jones Industrial Average) plays a greater role in explaining changes in ITT compared JCI, EXCRATE (exchange rate), and PI (Production Index). The financial crisis that hit the United States to led to a global recessiondue to the significant role of the United States in the world economy. 
The U.S. economy is one of the world's largest economies. This is reflected in its GDP that reached USD 15.5 trillion at the end of 2011, or a quarter of total world GDP. The U.S. trade balance is always in deficit. This is due to the high number of residents of the United States of 306 million people so the demand for clothing, food, goods and shelter is high. On the other hand, three-quarters of the working population is in the tertiary sector (service industry) and not in the secondary sector (manufacturing industry) or the primary sector (mining, fisheries, and agriculture), so it cannot meet the high primary needs in the country. Although Indonesia is not its main country of origin of imports, Indonesia is one of the main countries of origin for U.S. imports of natural rubber commodity, crude oil, bauxite and aluminum, industrial organics chemical, tin and aluminum processed products, processed rubber products, processed products palm oil, fishery products, and textile. Conversely, U.S. export commodities to Indonesia are wheat, passenger aircraft, machinery, and cars. With such a relationship, the crisis in the U.S. would have a major impact on trade volumes to Indonesia.

On the financial side, the crisis in the U.S. raised the issue of liquidity of U.S. financial firms as the Lehman Brothers (the fourth-largest financial company in the U.S.) went bankrupt. This caused the decline of the Dow Jones. The Dow Jones Industrial Average (DJI) is an indicator of the state of the financial sector (capital markets), so changes in the value of the DJI would affect investors' the decisions and confidence in investing. The decline of the Dow Jones, liquidity problems and high levels of debt caused the U.S. recession affecting the purchasing power of the U.S. In terms of international trade, decline in purchasing power would also affect U.S. import demand which would in turn affect world export demand. Countries that were directly affected are the countries that make the U.S. its largest export market, namely China, Japan, Germany, and Indonesia. This would reduce the level of Indonesian exports and directly impact on international tradetax income.

\section{CONCLUSIONS}

Referring to the empirical analysis this paper provides two (2) conclusions; first, the crisis in the United States has a significant effect on the capital market in Indonesia. Movement of the Jakarta Composite Index (JCI) delivers a proven direct response to Dow Jones Industrial Average (DJI). Changes in the Dow Jones Industrial Average (DJI) have a larger role in explaining movements of the Jakarta Composite Index $(\mathrm{JCI})$ than the exchange rate, the Production Index (PI), and the International Trade Tax (ITT). The first conclusion is consistent with the fact that Indonesia's capital market is still strongly influenced by foreign capital markets, so that the event of a large shock on foreign stock indices will easily cause panic among domestic investors.

In connection with trade, the shock on the Dow Jones Industrial Average (DJI) will be positive response on the Trade Tax International (ITT), which means that if there is an increase in the Dow Jones Industrial Average (DJI), the International Trade Tax (ITT) will go up, and vice versa. Changes in the Dow Jones Industrial Average (DJI) play a greater role in explaining changes 
in International Trade Tax (ITT) than the other three variables, namely the Jakarta Composite Index $(\mathrm{JCI})$, exchange rate (EXCRATE), and Production Index (PI). This means that the Jakarta Composite Index (JCI) effecton the International Trade Tax (ITT) is more significant than other variables. Shock on the Dow Jones Industrial Average would affect liquidity of the USD in the United States domestic market that will affect the purchasing power and Indonesian exports to the United States. Changes in the purchasing power will also affect U.S. import demand which impact on the world export demand. Countries that were directly affected are the countries that make the U.S. their largest export market, namely China, Japan, Germany, and Indonesia. This will reduce the level of Indonesian exports and directly impact on reception duties (International Trade Tax). These results lead to the conclusion that the crisis in the United States both affects the volume of trade and the taxation of international income.

It should be emphasized the needs to internalize other important variables into the model. In addition, the determination of restrictions on the estimated SVAR models can be studied further to provide more accurate results. Both of these opportunities would further research.

The conclusion of this paper has policy implications in the event of a crisis for example a marked significant decline in the Dow Jones index. The Capital Market and Financial Institution Supervisory Board (BAPPEPAM-LK), as a regulator of stock trading on the stock exchange, may intervene when there is a drop in stocks that go beyond the psychological threshold and/or halt trading on the Stock Exchange for a period of time. This is in accordance with Article 5 of Act 8 of 1995 regarding Capital Market. BAPPEPAM-LK can urge member companies to limit the exchange of securities using a margin threshold to protect the interests of investors from the use of debt. Besides that BAPPEPAM-LK can support a socialization program of investment in the capital market for the community, there by increasing the domestic (local) investor base.

Related to the effect of an external crisis concerning the decline in International Trade Tax, the Ministry of Commerce should encourage diversification of export destinations. This is in line with efforts to reduce dependence on exports of Indonesia to the United States.

For the Ministry of Industry, the conclusions in this paper imply the need to improve the quality and value-addedof export commodities. Attempts by the government to improve the quality of these goods could include provisions in education, training, and mentoring for entrepreneurs (exporters), both large and small. Providing additional capital for small entrepreneurs or SME's is necessary for small businesses with bright prospects to grow in the international market. The government can also work with national banks or local banksin providing credit with low interest charged. In addition, the Ministry of Industry could encourage the promotion of value-added products or value-added exports. 


\section{REFERENCES}

Ajija, Shochrul, 2011, et.al. 'Cara Cerdas Menguasai Eviews'. Salemba Empat

Allen, Franklin, 2001, 'Financial Structure and Financial Crisis'. Wharton School, University of Pennsylvania, International Review of Finance.

Bilmeier and Bonatot, 2002, 'Exchange Rate Pass-Through and Monetary Policy in Croatia'

Bappenas, 2009, 'Kebijakan Nasional Dalam Mencegah dan Mengantisipasi Dampak Krisis Keuangan Global', Buku Pegangan, 2009.

Crockett, Andrew, 1997, 'Why is Financial Stability a Goal of Public Policy', In Maintaining Financial Stability in a Goal Economy, A Symposium Sponsored by The Federal Reserve Bank of Kansas City, Jackson Hole, Wyoming.

Eichengreen, Barry and Richard Portes, 1987, 'The Antomy of Financial Crises', Working Paper No. 2126. National Bureau of Economics Research, Cambridge.

Enders, Walter, 2003, 'Applied Econometric Time Series', lowa State University.

Fang, Wenshwo, Yihao Lai, and Henry Thompson, 2007, 'Exchange Rate, Exchange Risk, and Asian Export Revenue', International Review of Economics and Finance16 : 237-254.

Fang, Wenshwo, Yihao Lai, and Stephen M Miller, 2009, 'Does Exchange Rate Risk Affect Exports Asymmetrically?', Journal of International Money and Finance 28: 215-239.

Nachrowi, D Nachrowi., and Hardius Usman, 2006, 'Pendekatan Populer dan Praktis Ekonometrika Untuk Analisis Ekonomi dan Keuangan', Depok, LP FE UI.

Sims, C. A., 1980, Macroeconomics and reality, Econometrica, 48(1):1-48.

Zhang, Wenlang, Zhiwei Zhang, and Gaofeng Han, 2010, 'How Does the US Credit Crisis Affect The Asia Pasific Economies? Analysis Based on A General Equilibrium Model', Journal of Asian Economics 21 : 280-292. 